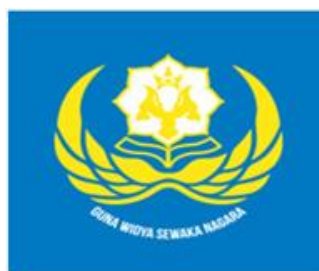

Linguistic Community Services Journal | Vol. 2, No. 1, 2021

P-ISSN: 2406-9019| E-ISSN: 2443-0668

Available online at

https://www.eiournal.warmadewa.ac.id/index.php/licosiournal

DOI: https://doi.org/10.22225/licosjournal.v2i1.2940 1-4

\title{
ENGLISH COURSE SEBAGAI MEDIA PENINGKATAN SUMBER DAYA MANUSIA WARGA BR. BABAKAN CANGGU, KUTA UTARA-BADUNG
}

\author{
I Made Juliarta \\ Universitas Bali Dwipa, Denpasar, Bali-Indonesia \\ madejuliarta@balidwipa.ac.id
}

\begin{abstract}
Abstrak
Kegiatan pengabdian kepada masyarakat ini bertujuan untuk meningkatkan kualitas sumber daya manusia yang mana dilakukan dengan cara pelatihan bahasa Inggris. Kegiatan ini dikemas dalam bentuk English Course/Pelatihan bahasa Inggris dasar. Program ini diprakarsai berkat kerjasama antara pendidik sendiri dengan mayarakat Br Babakan Canggu, dan konsultan bahasa Canggu guna mempersiapkan sumber daya manusia yang siap bersaing di dunia kerja pada era 4.0 saat ini. Penyelenggaraan kursus/pelatihan bahasa Inggris ini diselenggrakan selama 4 bulan di wilayah Br. Babakan Canggu Kuta Utara, Badung. Metode persuasif diaplikasikan dalam proses pembelajaran dengan jenis penelitian kualitatif. Sedangkan metode pengumpulan data berdasarkan observasi dengan mengamati fenomena yang terjadi dilapangan. Pelatihan yang diberikan kepada peserta antara lain berupa pelatihan bahasa Inggris level dasar, dan pelatihan bahasa Indonesia bagi penutur asing. Semua peserta pelatihan bahasa Inggris sangat antusias dalam mengikuti proses pelatihan bahasa Inggris yang diadakan atas kerjasama dengan lembaga konsultan bahasa dan masyarakat Br Babakan Canggu, Kuta Utara, Badung. Proses pelatihan bahasa Inggris yang diberikan kepada warga babakan, canggu didasari atas tulus iklas.
\end{abstract}

Kata Kunci: Field; Pelatihan; Pengabdian; Tenor

\section{Abstract}

This community service activity aims to improve the quality of human resources which is carried out by means of English language training. This activity is packaged in the form of an English Course / basic English training. This program was initiated thanks to the collaboration between the educators themselves and the Br Babakan Canggu community, and the Canggu language consultant to prepare human resources who are ready to compete in the world of work in the current 4.0 era. This English course / training was held for 4 months in the Br. Babakan Canggu North Kuta, Badung. The persuasive method is applied in the learning process with this type of qualitative research. While the data collection method is based on observation by observing the phenomena that occur in the field. The training provided to the participants included basic level English language training and Indonesian language training for foreign speakers. All English language training participants were very enthusiastic in participating in the English training process which was held in collaboration with the language and community consultancy agency Br Babakan Canggu, North Kuta, 
Badung. The process of English training provided to Babakan, Canggu residents was based on sincere sincerity.

\section{Keywords: Field; Training; Community Service; Tenor}

\section{PENDAHULUAN}

Perkembangan teknologi informasi bisa membawa dunia memasuki era baru yang lebih cepat dari yang kita bayangkan sebelumnya. Hal ini membawa perubahan dalam berbagai bidang kehidupan manusia dan dapat membawa berbagai perubahan di berbagai bidang kehidupan manusia saat ini. Bahasa Inggris mulai masuk ke Indonesia pada masa penjajahan Inggris ketika berada di Indonesia. Inggris telah menjajah banyak negara di seluruh benua pada masa itu, maka dari itu banyak negara yang menggunakan bahasa Inggris sebagai bahasa resmi dan bahasa Internasional, oleh karena itu dapat lebih mudah mengikuti perkembangan di dunia. Hingga kini bahasa Inggris digunakan sebagai mata pelajaran wajib bagi peserta didik dari tingkat taman kanak-kanak sampai perguruan tinggi. Bahasa Inggris bisa menjadi mata pelajaran yang bisa di UN-kan. Bahasa tersebut merupakan bahasa yang sangat penting untuk dipelajari karena dapat menjadi faktor penentu dalam mencapai kemajuan suatu bangsa. Dampak positif dari penggunaan bahasa Inggris adalah dapat mengikuti perkembangan di dunia. Tidak dapat dipungkiri bahwa bahasa asing di negara Indonesia yang mempunyai peranan yang besar bagi Indonesia itu sendiri.

Penguasaan bahasa Inggris sebagai bahasa internasional memiliki peranan yang sangat penting guna menghadapi kemajuan teknologi sebab bahasa asing memliki peranan yang sangat penting guna menghadapi kondisi saat ini. Bahasa Inggris dianggap memiliki peranan yang penting bagi kemajuan masyarakat di Indonesia. Dengan menggunakan metode deskriptif, dapat diketahui peranan bahasa Inggris dalam dunia pendidikan di Indonesia yang dimana bahasa tersebut memiliki peranan yang sangat penting dan berpengaruh dalam pendidikan yang ada di Indonesia.

Penulis yang memiliki keahlian di dalam memberikan pelatihan bahasa Inggris bagi masyarakat $\mathrm{Br}$ babakan, canggu dipandang sebagai orang yang tepat di dalam memberikan pelatihan bahasa Inggris. Bahasa Inggris sebagai bahasa Internasional yang banyak digunakan baik dalam dunia kerja di bidang pariwisata, pendidikan, dll. Pendidik memiliki pengalaman dalam bidang pengajaran di bidang pariwisata kesehatan, dunia kerja, yang dianggap mampu dan ahli dalam memberikan pelatihan program bahasa Inggris.

Berdasarkan penjelasan di atas, pelatihan bahasa Inggris diberikan kepada warga $\mathrm{Br}$ Babakan canggu oleh pendidik dengan senang hati. Dengan begitu, kegiatan pelatihan bahasa Inggris bisa berjalan dengan efektif karena dilakukan dengan rasa senang hati dan persuasif.

\section{METODE PENELITIAN}

Penelitian ini banyak membicarakan tentang peran bahasa Inggris terhadap dunia pekerjaan dan pendidikan di Indonesia. Laporan ini menggunakan metode penelitian kualitatif. Bogdan dan Taylor dalam Moleong (2010:4) menjelaskan tentang metodologi kualitatif sebagai prosedur penelitian yang menghasilkan data deskriptif berupa kata-kata tertulis atau lisan dari orang-orang dan perilaku yang bisa kita amati. Menurut Muhammad (2011: 30) penelitian kualitatif merupakan jenis penelitian dengan paradigma pos-positivism, yang memiliki tujuan untuk menafsirkan objek yang akan diteliti, dengan menggunakan beberapa metode dan dilaksanakan pada latar alamiah. Menurut Ismawati (2012: 9) penelitian kulitatif merupakan metode kualitatif karena beberapa faktor. Seperti diantaranya pertama, lebih mampu mengungkap realitas ganda, kedua, lebih mengungkapkan hubungan wajar antara peneliti dengan responden, dan ketiga, adalah metode kualitatif yang lebih sensitif dan adaptif terhadap peran sebagai pengaruh timbal balik. Sedangkan pendekatan yang diaplikasin yaitu 
pendekatan persuasif. Menurut Burgon \& Huffner (2002) Pendekatan persuasif merupakan persuasif merupakan pendekatan yang diberikan dalam proses pembelajaran, guna memberikan motivasi dalam proses pembelajaran serta pendekatan yang menggunakan pilihan kata yang mudah diingat sehingga para siswa lebih mudah untuk memahami bahasa Inggris.

Pada kegiatan pelatihan bahasa Inggris menggunakan data primer yang dimana terjadinya interaksi antara peserta didik dan pengajar contohnya pendidik mengajar dengan gerakan tubuh guna mempercepat pemahaman peserta didik. Di dalam memberikan pelatihan bahasa Inggris tingkat dasar, gerakan tubuh diperlukan guna mempercepat pemahaman dan kegiatan belajar mengajar menjadi lebih efektif dan mudah dimengerti/dipahami. Peserta yang sangat antusias membuat pendidik bersemangat di dalam memberikan pelatihan bahasa Inggris kepada warga yang tinggal di sekitar wilayah Br Babakan, Canggu-Badung, Bali. Peserta didik juga diharapkan dapat memperaktikkan ilmu yang diperoleh ketika menjalani pelatihan Bahasa Inggris yang diadakan di wilayah Br babakan, Canggu-Badung Bali.

Pada bagian akhir dari karya tulis ini, juga disajikan beberapa foto kegiatan selama peroses pelatihan bahasa Inggris yang diadakan di wilayah canggu Bali. Sajian dalam laporan karya tulis ini dianggap penting untuk sebagai bukti bahwa program ngayah tersebut telah dilakukan dengan baik untuk mempersiapkan skill/kemampuan sumber daya manusia yang bagus

\section{HASIL DAN PEMBAHASAN}

Peserta didik yang mengikuti pelatihan bahasa Inggris ini merupakan warga yang tinggal di wilayah Br. Babakan Canggu, Bali. Materi bahan ajar yang diberikan yaitu mencakup tentang grammar, kosa kata, bahasa Inggris umum, tenses, dan materi lainnya yang berkaitan tentang bahasa Inggris umum tingkat dasar. Di dalam memberikan pelatihan Bahasa Inggris, pendidik juga memberikan selingan materi Bahasa Inggris dalam bentuk listening. Listening yang diberikan berupa materi dasar bahasa Inggris yang mana materinya mudah dipahami oleh semua peserta pelatihan bahasa Inggris tingkat dasar. Listening juga diselingi dengan memberikan quiz atau latihan latihan bahasa Inggris dalam listening yang mudah dimengerti oleh semua peserta pelatihan bahasa Inggris ini.

Membaca atau dalam bentuk reading juga diberikan kepada semua peserta pelatihan Bahasa Inggris sehingga memudahkan para peserta untuk menguasai kemampuan menganalisis paragrap atau bacaan dalam bahasa Inggris. Bahan ajar membaca tingkat dasar diberikan kepada peserta pelatihan yang mana juga diselingi dalam hiburan games atau permainan guna menghilangkan rasa jenuh atau bosan ketika proses pembelajaran berlangsung. Teks atau bacaan yang diberikan merupakan materi yang menyenangkan guna menghilangkan kepenatan belajar mengajar di kelas.

Kegiatan menulis atau dalam bentuk writing juga diberikan kepada peserta pelatihan bahasa Inggris di Br Babakan, Canggu Bali guna mengasah atau melatih kemampuan menulis dalam bentuk writing/menulis kepada para peserta pelatihan bahasa Inggris tingkat dasar ini. Beberapa peserta pelatihan bahasa Inggris ini nampak sangat antusias di dalam melaksanakan kegiatan ini. Kegiatan ini dilaksanakan di dalam ruangan kelas, sehingga para peserta merasa sangat nyaman ketika mengikuti peroses pelatihan bahasa Inggris tinglat dasar ini. Dengan melaksanakan latihan menulis atau writing, para peserta didik menjadi lebih memahami struktur grammar dalam bahasa Inggris. Karena di dalam writing atau menulis dalam bahasa Inggris, pemahaman gramar sangat penting guna meningkatkan kemampuan atau skill para peserta pelatihan bahasa Inggris. 


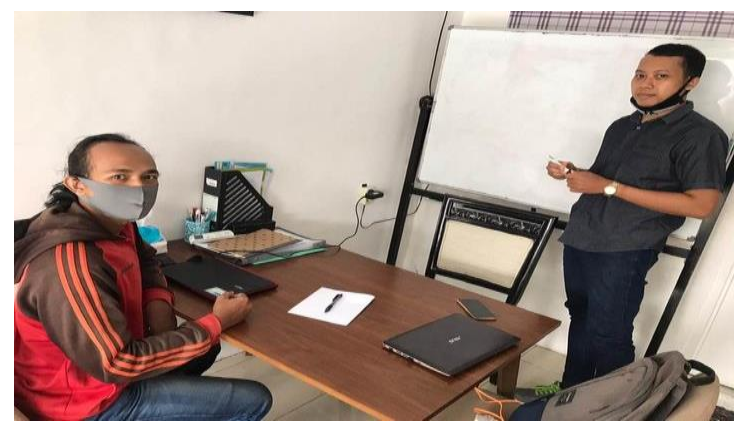

Gambar 1. Kondisi siswa saat mengikuti kegiatan pembelajaran

\section{IV.SIMPULAN DAN SARAN}

Kegiatan pelatihan ini diadakan di wilayah Br Babakan, Desa Canggu, Kabupaten Badung. Materi yang diberikan di dalam bentuk reading/bacaan diberikan kepada para peserta pelatihan bahasa Inggris dasar. Kegiatan menulis/writing juga diberikan Dengan melaksanakan kegiatan menulis atau writing, para peserta didik menjadi lebih memahami struktur grammar dalam bahasa Inggris guna meningkatkan kemampuan atau skill para peserta pelatihan bahasa Inggris yang sangat berguna kedepannya.

\section{DAFTAR PUSTAKA}

Burgon \& Huffner. 2002. Human Communication. London: Sage Publication Chaer, A. 2013. Pembinaan Bahasa Indonesia. Jakarta: PT Rineka Cipta.

Ismawati, Esti. 2012. Metode Penelitian Pendidikan Bahasa dan Sastra. Yogyakarta: Penerbit Ombak.

Moleong. 2010. Metodologi Penelitian Kualitatif. Bandung: PT Remaja Rosdakarya.

Muhammad. 2011. Metode Penelitian Bahasa. Jogjakarta: Ar-Ruzz Media.

Muslich, M. 2010.Bahasa Indonesia Pada era Globalisasi. Jakarta: PT Bumi Aksara.

Murti, Sri. Eksistensi Penggunaan Bahasa Indonesia di Era Globalisasi. Prosiding Seminar bulan Bahasa UNIB 2015. hlm:177-184.

Nisa, K \& Imam Suyitno. 2017. Kesalahan Penggunaan Bahasa Indonesia dalam Teks Terjemahan Mahasiswa. Jurnal Basindo, 1(1).

Pamungkas, Sri. 2012. Bahasa Indonesia dalam berbagai perspektif. Yogyakarta: Penerbit Andi.

Paryono, Y. 2013. Peran Strategis Media Massa Dalam Pembinaan Dan Pengembangan Bahasa Indonesia. Jurnal Madah. 4(2). 